\title{
Energy requirements for maintenance of ion concentrations in roots
}

\author{
T. J. Bouma and R. De Visser
}

Bouma, T. J. and De Visser, R. 1993. Energy requirements for maintenance of ion concentrations in roots. - Physiol. Plant. 89: 133-142.

Maintenance of ion gradients across plant membranes is considered to be an important process requiring respiratory energy in plant tissues. In order to test this hypothesis, roots of intact plants of potato (Solanum tuberosum L. cv. Alcmaria and cv. Pimpernel) were incubated in a closed circulation system. Electrical conductivity of the solution surrounding these roots was continuously monitored to determine total ion efflux into demineralized water. Anion efflux rate from the symplast was 35 neq ( $g$ dry weight $)^{-1} \mathrm{~s}^{-1}$. In combination with literature data on the specific costs of ion transport, this efflux rate yields the respiration rate associated with re-uptake balancing efflux (i.e. maintenance of cellular ion concentrations). The results suggest that energy costs associated with re-uptake of ions may account for up to $25-50 \%$ of the total respiratory costs involved in ion influx.

Key words - ATP costs, efflux, electrical conductivity, electrolyte leakage, energy costs, influx, ion uptake, maintenance, potato, respiration, roots, Solanum tuberosum.

T.J. Bouma (corresponding author), Dept of Theoretical Production Ecology, Wageningen Agricultural Univ. and Centre for Agro-biological Research (CABO-DLO), PO Box 430, NL-6700 AK Wageningen, The Netherlands; $R$. DeVisser, Centre for Agro-biological Research (CABO-DLO), PO Box 14, NL-6700 AA Wageningen, The Netherlands.

\section{Introduction}

Up to $50 \%$ of the photosynthates produced daily are respired (Lambers 1985). Depending on plant growth rate and age, $20-60 \%$ of the respiratory energy may be used for maintenance processes (Amthor 1984, Van der Werf et al. 1988). Knowledge about these maintenance processes. will improve our understanding of plant growth and crop yield. A major part of the maintenance energy costs is supposed to be associated with (1) the maintenance of ion gradients across membranes and (2) protein turnover (Penning de Vries 1975). The energy demands of these processes in vivo are not well known and estimates are scarce (Amthor 1984). Recently, De Visser et al. (1992) showed that the specific energy costs of protein biosynthesis and turnover may well be twice as high as calculated before by Penning de Vries (1975). However, little work has been reported on the energy costs of maintenance of ion gradients across

Received 9 March, 1993; revised 14 May, 1993 membranes (i.e. maintenance of cellular concentrations) in whole plants, and it is the purpose of the present paper to approach this aspect.

The plant maintains a constant membrane potential and a constant composition of the cytosol (Lauer et al. 1989, Tomos and Wyn Jones 1988). Here we address the question whether maintaining ion concentrations under steady-state conditions in roots is quantitatively important for their total energy requirements. The energy requirements for maintenance of ion concentrations are calculated as the product of the specific costs of ion uptake as derived from literature data and the fraction of active transport that compensates for efflux. This fraction of transport is estimated as being quantitatively equivalent to the rate of total ion efflux from intact roots in demineralized water, as measured by monitoring the electrical conductivity of the medium. However, efflux not involving energy-dependent re-uptake, like efflux from the free space and efflux of some cations 
(e.g. cellular potassium) from the symplast, must be excluded in these calculations. Therefore, the efflux kinetics from the Donnan phase and the nature of the cations in the efflux medium and root extracts have been experimentally determined.

Abbreviations - Dp, Donnan phase; EC, electrical conductivity; eq, mol equivalent charge; RGR, relative growth rate; WFS, water free space.

\section{Materials and methods}

Plant material

Potato plants (Solanum tuberosum L. cv. Alcmaria and cv. Pimpernel) were propagated by in vitro culture, and grown in a circulating aerated Hoagland solution [macro nutrients at $1 / 2$ strength according to Hoagland and Snijder (1933) and micro nutrients at $1 / 2$ strength according to Lewis and Powers (1941), with $90 \mu M$ iron as $\mathrm{Fe}$ (III)-EDTA]. Entangling of the roots of neighbouring plants was prevented. A uniform supply of nutrients was provided for each individual plant by rapid circulation from a central storage vessel. The light conditions were: $12 \mathrm{~h} 240 \mu \mathrm{mol} \mathrm{m}^{-2} \mathrm{~s}^{-1}$ PPFD provided by fluorescent tubes (Philips TLD 36W/54) and incandescent lamps (Pope $60 \mathrm{~W}$ ) in a ratio 12:1. Incandescent light (Pope $60 \mathrm{~W}$ ) was supplied for another $6 \mathrm{~h}$ after the 12-h light period, to prevent tuber induction. Temperature was $18 \pm 2{ }^{\circ} \mathrm{C}$, and relative air humidity $70 \%$. In all experiments vegetative plants were used at various ages ranging from 18 to 48 days.

\section{Electrical conductivity measurements}

Before transfer to the experimental set-up, roots of intact plants were gently rinsed in two separate volumes $(500 \mathrm{ml})$ of demineralized water for less than a min in order to remove adhering nutrient solution. The roots were then incubated in a circulation system filled with demineralized water (Fig. 1) to monitor net charge efflux by electrical conductivity (EC). The EC was measured using a WTW LF530 conductivity meter and WTW LTA01 electrode, and a WTW TFK 530 sensor for automatic temperature compensation (Wissenschaftlich-Technische Werkstatten $\mathrm{GmbH}$, Weilheim, Germany) and expressed in $\mu \mathrm{S} \mathrm{cm}^{-1}$. Efflux was calculated from the slope of the change of EC against time at various moments after start of the incubation. At the end of some of the experiments ( 2 to $29 \mathrm{~h}$ after start of incubation; $n=5$ ), the medium was sampled to obtain an estimate of the relative contribution of the different cations to the efflux.

Our objective was to prevent re-uptake during efflux by maintaining the external concentrations low compared to the $\mathrm{k}_{\mathrm{m}}$ of the uptake system. The concentration in the circulation system (Fig. 1) is determined by the efflux rate integrated over the experimental time $\left(\int \Phi^{\mathrm{io}} \mathrm{dt}\right.$, on a dry weight basis) multiplied by root dry weight and divided by the volume of the system (V). This volume $(300 \mathrm{ml})$ was a compromise between (1) the ideal infinite volume (a zero source for uptake) and (2) a small volume/root-weight ratio to enable detection of changes in EC. Efficient mixing is required to minimize development of boundary layers close to the roots. Since the EC electrode is sensitive to electromagnetic fields, the medium was mixed by circulation with a pump (Iwaki magnet pump model md-6, max capacity 8 to $91 \mathrm{~min}^{-1}$; Iwaki CO., Ltd., Tokyo, Japan). As indicated by the rapid changes in EC after injection of salt solutions, the mixing rate was adequate for the time resolution required (equilibration time less than $1 \mathrm{~min}$ ). All other conditions were similar to the growth conditions.

The circulation system could be changed from a 300 $\mathrm{ml}$ closed system (valve 8 open, valves 9 closed) to an open system (valve 8 closed, valves 9 open), in which the medium was continuously replaced (Fig. 1). Preliminary measurements showed no significant differences in efflux between the two systems, indicating that the closed system behaves like a zero source of ions for re-uptake over the experimental period. Further experiments were performed with the closed system.

\section{Calculation of ion efflux from electrical conductivity measurements}

The efflux measured as the change of EC of the medium $\left(\triangle E C, \mathrm{mS} \mathrm{m}^{-1} \mathrm{~s}^{-1}\right)$ was transformed to a charge equivalent basis. Ion efflux of roots $\left(\Phi_{\text {eq }}^{\text {io }}\right.$, eq $(\mathrm{g} \mathrm{DW})^{-1} \mathrm{~s}^{-1}$; eq is one mol charge equivalents) is calculated according to:

$\Phi_{\mathrm{eq}}^{\mathrm{io}}=(\Delta \mathrm{EC} \times \mathrm{V}) /\left(\Lambda_{\mathrm{a}} \times \mathrm{DW}\right)$

where $\mathrm{V}$ is the volume of the measuring system $\left(\mathrm{m}^{3}\right), \Lambda_{\mathrm{a}}$ is the average conductance of equivalent charge $(\mathrm{mS}$ $\mathrm{eq}^{-1} \mathrm{~m}^{2}$ ) and DW is the dry weight of the root $(\mathrm{g})$.

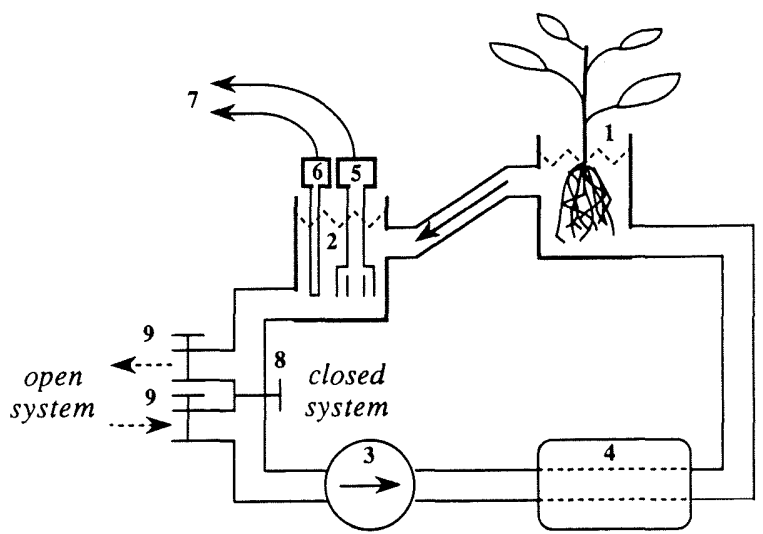

Fig. 1. Incubation system for monitoring electrolyte efflux from intact roots. 1, Plant cuvette; 2 , electrode cuvette; 3 , pump; 4 , temperature control; 5 , EC electrode; 6 , thermocouple; 7, EC meter; 8 and 9, valves. 
Although the relationship between conductance $(\Lambda)$ and concentration is complex (Chang 1981), it is linear for strong electrolytes at the low concentrations used here. This was verified by calibration with 0 to $1 \mathrm{mM}$ $\mathrm{KNO}_{3}$ and $\mathrm{KCl}\left(\mathrm{r}^{2}>0.99\right)$. The molar conductances as calculated from single ions (after Anonymous 1978), agreed well with our calibrations. Because of the small differences between ion species in $\Lambda$ (after Anonymous 1978), the overall conductivity of a mixture of ions as expressed on electronic charge basis is hardly affected by the chemical nature of the ions (except for protons and hydroxyl anions). Therefore, the average conductance of equivalent charge $\left(\Lambda_{\mathrm{a}}=6.42 \mathrm{mS} \mathrm{eq}^{-1} \mathrm{~m}^{2}\right)$ was calculated as the average of the average equivalent conductances of $\mathrm{K}^{+}$and $1 / 2 \mathrm{Ca}^{2+}(6.05)$ and the average of $\mathrm{NO}_{3}^{-}, \mathrm{Cl}^{-}$and $1 / 2 \mathrm{SO}_{4}^{2-}(6.79$; after Anonymous 1978) at the same temperature as used for automatic correction of the output values by the WTW LF $530\left(20^{\circ} \mathrm{C}\right)$.

\section{Kinetics of loss from the Donnan phase}

To enable correction for total efflux from the free space (i.e. loss from the Donan phase [Dp] and WFS), data on the kinetics of the slowest component of this efflux (i.e. the efflux from the Dp) were used. Cell wall calcium, a major component of the Dp, is reversibly exchangeable against magnesium (Sentenac and Grignon 1981), which is mainly located in the symplast (Hanson 1984). Therefore, we measured the reversible exchange of calcium for magnesium and used these data to calculate the half-life of the $\mathrm{Dp}\left(\mathrm{t}_{1 / 2}\right)$ according to:

$$
\mathrm{t}_{1 / 2}=(-\mathrm{t} \ln 2) /\left(\ln \mathrm{V}_{\mathrm{t}}-\ln \mathrm{V}_{\mathrm{t} 0}\right)
$$

where $t$ is the time from the start of the exchange, $V_{t}$ is the rate of loss of ions from the free space at time $t$ and $V_{t 0}$ is the initial rate of loss, both proportional to the ion concentration in the free space. The reversible exchange was determined in vessels with a relatively small volume $(100 \mathrm{ml})$, to obtain levels of ions detectable by atomic absorption spectrometry within $10 \mathrm{~min}$. The medium was stirred by aeration, and could be rapidly changed without disturbing the roots, via a tap in the bottom of the vessel.

In the first experiment (Dp-1), two plants were used. With the first plant the exchange/efflux rates of calcium and magnesium were determined during incubations for one $\mathrm{h}$ each of the roots into successively (1) $\mathrm{MgCl}_{2}$, (2) $\mathrm{CaCl}_{2}$, (3) $\mathrm{MgCl}_{2}$, (4) $\mathrm{CaCl}_{2}$ and (5) demineralized water. Salt concentrations were $50 \mathrm{~m} M$. The second plant was used to measure the efflux of calcium and magnesium into (6) demineralized water for one $h$.

In the second $\mathrm{Dp}$ experiment $(\mathrm{Dp}-2)$, the efflux/exchange rates of calcium and magnesium were measured on 4 plants (two of each cultivar). The media were changed in the following order: incubations for one $h$ each in successively (1) demineralized water, (2) $\mathrm{MgCl}_{2}$, (3) $\mathrm{CaCl}_{2}$, followed by incubations of 30 min each in (4)
$\mathrm{MgCl}_{2}$, (5) $\mathrm{CaCl}_{2}$ and (6) demineralized water. Salt concentrations were $23 \mathrm{~m} M$.

During all incubations in both experiments Dp- 1 and $\mathrm{Dp}-2$, we replaced the medium every $10 \mathrm{~min}$, and kept it for chemical analyses. To remove adhering medium, roots were briefly washed twice in the type of medium to be used for the next treatment.

\section{Calculation of respiratory costs of re-uptake}

Efflux [ $\Phi_{\text {eq }}^{\text {io }}$; eq $\left.(\mathrm{g} \mathrm{DW})^{-1} \mathrm{~s}^{-1}\right]$ is expressed on a molar basis $\left[\Phi_{\mathrm{j}}^{\mathrm{i}}\right.$; mol ion $\left.\mathrm{j}(\mathrm{g} \mathrm{DW})^{-1} \mathrm{~s}^{-1}\right]$ by dividing half of $\Phi_{\mathrm{eq}}^{\mathrm{io}}$ by the ion valency of the average cat- or anion $j\left(z_{\mathrm{j}}\right)$. Due to electroneutrality the ratio anion/cation equivalents is 1 , and thus half of $\Phi_{\mathrm{eq}}^{\mathrm{io}}$ is for cations and half for anions.

$$
\Phi_{\mathrm{j}}^{\mathrm{io}}=0.5 \times \Phi_{\mathrm{eq}}^{\mathrm{io}} / \mathrm{z}_{\mathrm{j}}
$$

From this rate (after correction for the free space) and various literature data, the respiratory energy cost for re-uptake balancing efflux for either cat- or anions was calculated according to:

$\mathrm{m}_{\mathrm{c}-\mathrm{j}}=\Phi_{\mathrm{j}}^{\mathrm{io}} \times \mathrm{M}_{\mathrm{j}} \times\left(\mathrm{H} / \mathrm{I}_{\mathrm{j}}\right) \times(\mathrm{H} / \mathrm{P})^{-1}$

where $m_{c-j}$ is the energy cost for maintaining concentrations for ion $\mathrm{j}$ [mol ATP $(\mathrm{g} \mathrm{DW})^{-1} \mathrm{~s}^{-1}$ ], $\Phi_{j}^{\mathrm{i}}$ is the efflux of ion $\mathrm{j}$ [mol ion $\left.\mathrm{j}(\mathrm{g} \mathrm{DW})^{-1} \mathrm{~s}^{-1}\right], \mathrm{M}_{\mathrm{j}}$ is the number of active membrane passages of ion $\mathrm{j}, \mathrm{H} / \mathrm{I}_{\mathrm{j}}$ is the ratio between the protons and ion $\mathrm{j}\left[\mathrm{mol} \mathrm{H}^{+}(\mathrm{mol} \text { ion } \mathrm{j})^{-1}\right]$ and $\mathrm{H} / \mathrm{P}$ is the stoichiometry of the proton-ATPase [mol $\mathrm{H}^{+}$(mol ATP $)^{-1}$. By dividing $\mathrm{m}_{\mathrm{c}-\mathrm{j}}$ by the $\mathrm{P} / \mathrm{O}_{2}$-ratio of the oxidative phosphorylation [ $\mathrm{mol}$ ATP $\left(\mathrm{mol} \mathrm{O}_{2}\right)^{-1}$ ], the respiratory costs on an oxygen basis are obtained $\left[\mathrm{mol} \mathrm{O}_{2}\left(\mathrm{~g} \mathrm{DW}^{-1}\right]\right.$. Equation 4 describes the calculation method for secondary active anion transport. In case of re-uptake by primary active transport, the product $\left(\mathrm{H} / \mathrm{I}_{\mathrm{j}}\right) \times(\mathrm{H} / \mathrm{P})^{-1}$ should be replaced by the stoichiometry of the ion $\mathrm{j}$-ATPase $\left[\mathrm{P} / \mathrm{I}_{\mathrm{j}}\right.$, mol ATP $\left.(\mathrm{mol} \text { ion } \mathrm{j})^{-1}\right]$.

In our calculations we assumed one membrane passage to be involved in re-uptake balancing efflux. Transport (efflux and influx) of potassium does not require metabolic energy (Hedrich and Schroeder 1989) because the $\mathrm{K}^{+}$concentration is generally near the Nernst equilibrium. The proton:ATP stoichiometry of the proton-ATPase (H/P) is 2 (as measured for the tonoplast; Bennett and Spanswick 1984, Guern et al. 1989). Since the major anion absorbed is nitrate (Marschner 1989), we used the anion-valency $\left(\mathrm{z}_{\mathrm{j}}=1\right)$ and proton/ion ratio $\left(\mathrm{H} / \mathrm{I}_{\mathrm{j}}=2\right)$ of nitrate in our calculations. Under the present growth conditions, the potato plants had a relative growth rate (RGR) of $0.15 \mathrm{~g}(\mathrm{~g} \mathrm{DW})^{-1}$ day $^{-1}$ (Bouma et al. 1992). We assumed an average alternative pathway activity of $30 \%$ [P/O-ratio of 2.4; after Tab. 3 in Poorter 
et al. (1991) for plants with a RGR less than $0.2 \mathrm{~g}$ ( $\mathrm{g}$ $\mathrm{DW})^{-1}$ day $\left.^{-1}\right]$.

Chemical analyses of root extracts, media from exchange experiments, and media from efflux measurements

In order to relate leaking electrolytes to the cellular ionic contents, two roots of control plants were extracted by boiling for $5 \mathrm{~min}$ in $200 \mathrm{ml}$ demineralized water. Before extraction, the roots were washed in demineralized water. Both extracts and samples of the efflux media of the EC measurements were analyzed for $\mathrm{K}^{+}, \mathrm{Fe}^{2+13+}, \mathrm{Mg}^{2+}, \mathrm{Ca}^{2+}$ and $\mathrm{Na}^{+}$, whereas the samples of Dp-1 and Dp-2 were analyzed for $\mathrm{Mg}^{2+}$ and $\mathrm{Ca}^{2+}$. All cation analyses were done by atomic absorption spectrometry (VARIAN SpectrAA-10, Varian Techtron Pty. Ltd., Springvale, Australia). All data were corrected for the mineral content of demineralized water samples stored under identical conditions as the efflux media and extracts.

\section{Statistics}

The $95 \%$-probability intervals for efflux (EC measurements) and exchange (experiment Dp-2) rates were calculated using Student's $t$-values.

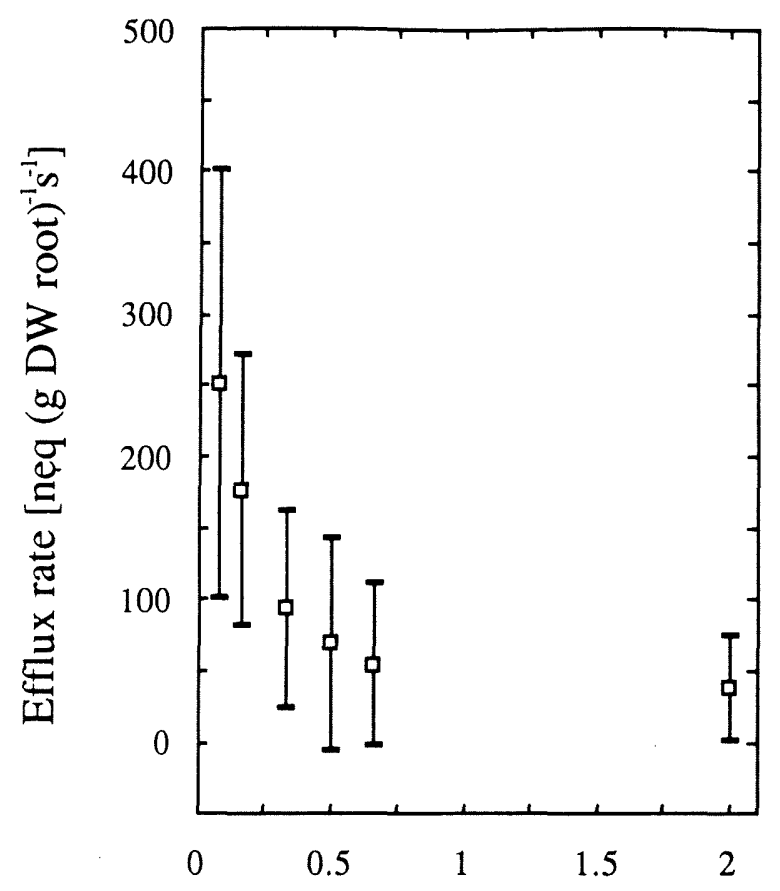

\section{Time (h)}

Fig. 2. Efflux of charge equivalents [neq $(\mathrm{g} \mathrm{DW})^{-1} \mathrm{~s}^{-1}$ from potato roots incubated in demineralized water. Bars indicate $95 \%$-probability intervals.

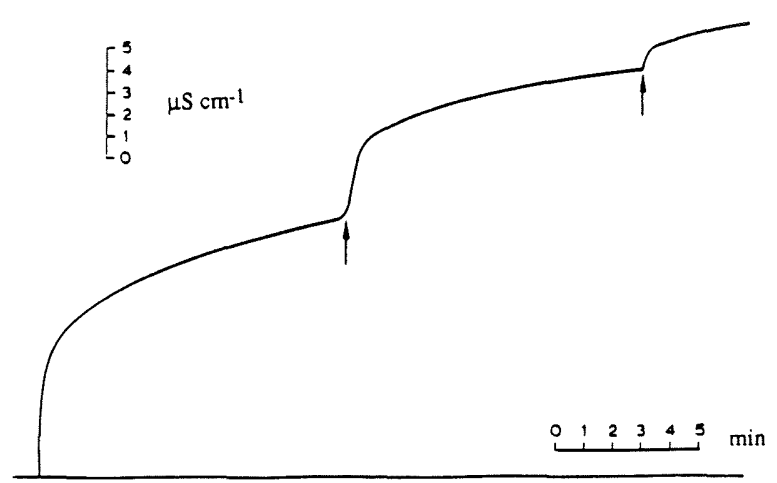

Fig. 3. Stimulation of root efflux rate in response to removing the plants from the incubation system and then immediately returning them to the original position. The moments of the start of the treatment are indicated by arrows.

\section{Results}

Electrolyte efflux, and nature and half-life of the Donnan phase

Since there were no significant differences between the two potato cultivars, the time course data of the anion plus cation efflux [neq $(\mathrm{g} \mathrm{DW})^{-1} \mathrm{~s}^{-1}$ ] of both cultivars were combined (Fig. 2). Damaging the roots induced high ion efflux into demineralized water (data not shown). Gently removing the plants from this medium and immediate return to the original position also increased efflux (Fig. 3). However, comparison with efflux kinetics of untreated roots (Fig. 2) revealed that this increase was transient (duration less than $10 \mathrm{~min}$ ). The high initial efflux is partly due to previous treatments (rinsing and transfer) of the roots (cf. Fig. 3).

A comparison of the relative contribution of the cations released into the efflux medium with those in extracts of the roots showed that, although potassium was quantitatively the most important cation in the root (ca $77 \%$ ), calcium was the most abundant one in the efflux medium (ca $67 \%$ ). This calcium is unlikely to originate from the cytosol, because the cytosolic calcium concentration is tightly regulated at a very low level (ca $1 \times 10^{-6} M$; Lühring and Tazawa 1985, Williamson and Ashley 1982). Cell walls however, contain a large amount of calcium (Demarty et al. 1984), suggesting that the calcium in the efflux medium originated predominantly from the free space. Efflux of ions from the free space is not compensated for by active transport and was, therefore, excluded in calculations of respiratory costs of re-uptake balancing efflux.

Reversible exchange for magnesium showed that the Donnan phase contained calcium (Figs 4 and 5), with a half-life of ca 9 min (cf. eq. 2) as it decreased by at least $90 \%$ within half an hour (Figs $4 \mathrm{~A}$ and 5). The exchange could not be explained by adhering solution, because only little calcium was found in demineralized water after a $\mathrm{CaCl}_{2}$ treatment (Fig. $4 \mathrm{~A}$ ). Thus the adhering solution was effectively removed during rinsing between 


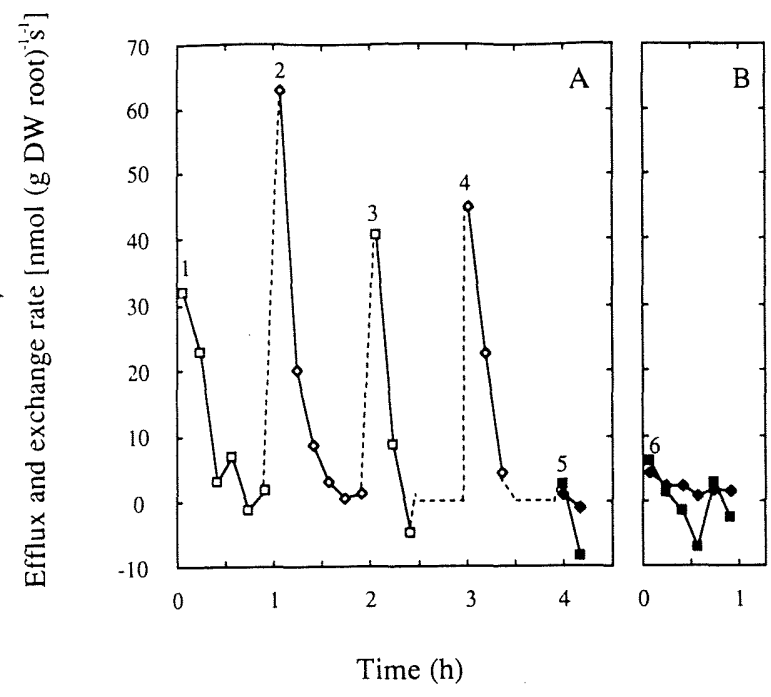

Fig. 4. The rate of exchange of calcium in $\mathrm{MgCl}_{2}$ ( $\square ; 1$ and 3) or magnesium in $\mathrm{CaCl}_{2}(\Delta ; 2$ and 4$)$ and the efflux of calcium (ם) and magnesium ( $)$ in demineralized water (5 and 6). The results of the different plants are shown in the figures $\mathrm{A}$ and $\mathrm{B}$ respectively. Full details are given in Materials and methods.

treatments. Negative values for the efflux in demineralized water (Fig. 4A, B) are due to the variation in the samples combined with the correction for the ion content of control samples of demineralized water.

\section{Calculation of respiratory costs of re-uptake}

Respiratory costs for re-uptake of anions lost by efflux $\left(m_{c}\right)$ were estimated according to equations 3 and 4 (Tab. 1). Efflux from the free space was excluded in calculations of respiratory costs by using the electrolyte efflux as measured after $30 \mathrm{~min}$. At this moment the remaining efflux originating from the free space is found to compensate approximately for the decrease in efflux from the symplast (details in discussion). Efflux data after $10 \mathrm{~min}$ and $2 \mathrm{~h}$ are presented to show the effect of a higher and lower efflux rate on respiratory costs (Tab. 1 ). In the calculations we assumed that (1) all calcium originates from the WFS and Dp, (2) the symplasmatic efflux consists of potassium accompanied by anions, resulting in overall electroneutrality and (3) the anions consist predominantly of nitrate. The calculated respiratory costs for re-uptake of anions lost by efflux $\left(\mathrm{m}_{\mathrm{c}}\right)$ after $10 \mathrm{~min}, 0.5 \mathrm{~h}$ and $2 \mathrm{~h}$ were 88,35 and $19 \mathrm{nmol}$ ATP $(\mathrm{g} \mathrm{DW})^{-1} \mathrm{~s}^{-1}$ or 18,7 and $4 \mathrm{nmol} \mathrm{O}_{2}(\mathrm{~g} \mathrm{DW})^{-1} \mathrm{~s}^{-1}$, respectively (Tab. 1).

\section{Discussion}

Evaluation of the electrical conductivity technique

Isotopic labelling is commonly used for examining inand efflux kinetics. A limitation of this laborious technique is the small number of ion species that can be handled in one experiment. Therefore, no overall measure of ion efflux is obtained. Electrolyte leakage, measured by electrical conductivity (EC), is a commonly used index of membrane integrity and thus potentially suitable for monitoring total ion efflux from intact plant roots. It has been used for the evaluation of the extent of (1) senescence of plant tissues (Borochov and $\mathrm{Fa}$ ragher 1983), (2) chilling injury (Hetherington et al 1988), (3) seed germination capacity (Senaratna et al. 1988) and (4) injury caused by herbicide surfactants (O'Donovan et al. 1983). Here we discuss the validity of measuring the efflux rate as change of $\mathrm{EC}$ in demineralized water, and consider the experimental problems in comparison with the labelling technique.

Calcium stabilizes membranes and shields negative charges (Ferguson 1984, Hanson 1984). No calcium was added to the efflux medium, because it lowers the sensitivity for measuring EC due to an increased background signal. In labelling experiments this technical limitation is absent. This lack of external calcium was not considered to be a problem as plants were grown with ample nutrients, the experiments were short, and requirements are at millimolar activities (Hanson 1984). Moreover, considering that the initial efflux consists mainly of calcium from the cell wall, the calcium concentration in the medium would reach the millimolar range within $10 \mathrm{~min}$.

The present method provides information on the kinetics of net ion efflux rates. Therefore, ion efflux may have been underestimated for two reasons. Firstly, total

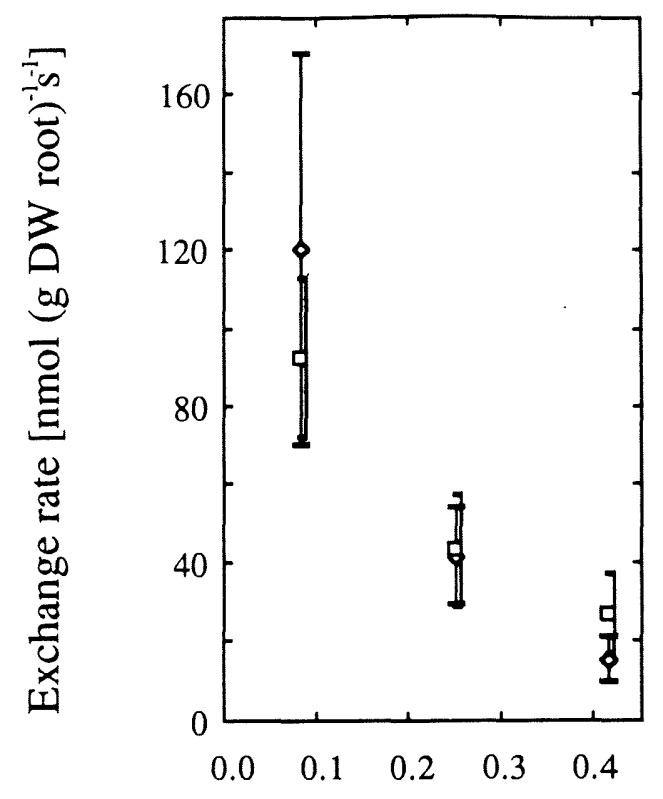

Time (h)

Fig. 5. The rate of efflux or exchange of magnesium in $0.023 \mathrm{M}$ $\mathrm{CaCl}_{2}(\diamond)$ and of calcium in $0.023 \mathrm{M} \mathrm{MgCl}_{2}(\square)$ after washing for $60 \mathrm{~min}$ in (a) $0.023 \mathrm{M} \mathrm{MgCl}_{2}$ and (b) $0.023 \mathrm{M} \mathrm{CaCl}_{2}$. Bars indicate $95 \%$-probability intervals. 
Tab. 1. Calculation of (1) the ATP costs, (2) the respiratory costs and (3) the fraction of literature values for total or maintenance respiration (references in last column), which are explained by re-uptake balancing efflux in roots (maintaining gradients). In the calculations we used an anion-valency $\left(\mathrm{z}_{\mathrm{j}}\right)$, proton/ion ratio $\left(\mathrm{H} / \mathrm{I}_{\mathrm{j}}\right)$ and the proton: ATP-ratio $(\mathrm{H} / \mathrm{P})$ of 1,2 and 2 , respectively.

\begin{tabular}{|c|c|c|c|c|c|}
\hline \multirow[t]{2}{*}{ Parameter } & \multicolumn{3}{|c|}{ Time $(\min )$} & \multirow{2}{*}{$\begin{array}{c}\text { ADP/O } \\
\text {-ratio }\end{array}$} & \multirow[t]{2}{*}{ References } \\
\hline & 10 & 30 & 120 & & \\
\hline $\begin{array}{l}\text { Leakage rates } \\
\mathrm{nS} \mathrm{m}^{2}(\mathrm{~g} \mathrm{DW})^{-1} \mathrm{~s}^{-1} \\
\text { neq }(\mathrm{g} \mathrm{DW})^{-1} \mathrm{~s}^{-1} \\
\text { neq }(\mathrm{g} \mathrm{FW})^{-1} \mathrm{~s}^{-1}\end{array}$ & $\begin{array}{l}1.13 \\
176 \\
11.8\end{array}$ & $\begin{array}{l}0.44 \\
69 \\
4.6\end{array}$ & $\begin{array}{l}0.25 \\
38.8 \\
2.6\end{array}$ & & \\
\hline $\begin{array}{l}\text { Costs for re-uptake (absolute values) } \\
\text { nmol ATP }(\mathrm{g} \mathrm{DW})^{-1} \mathrm{~s}^{-1} \\
\mathrm{nmol} \mathrm{O} \mathrm{O}_{2}(\mathrm{~g} \text { DW) })^{-1} \mathrm{~s}^{-1} \\
\mathrm{nmol} \mathrm{O}_{2}(\mathrm{~g} \mathrm{DW})^{-1} \mathrm{~s}^{-1}\end{array}$ & $\begin{array}{l}88 \\
14.7 \\
18.4\end{array}$ & $\begin{array}{r}34.5 \\
5.8 \\
7.2\end{array}$ & $\begin{array}{r}19.4 \\
3.2 \\
4.1\end{array}$ & $\begin{array}{l}3 \\
2.4\end{array}$ & \\
\hline $\begin{array}{l}\text { Fraction of root respiration } \\
\% \text { of } 355 \mathrm{nmol} \text { ATP }(\mathrm{g} \mathrm{DW})^{-1} \mathrm{~s}^{-1} \\
\% \text { of } 536 \mathrm{nmol} \text { ATP }(\mathrm{g} \mathrm{DW})^{-1} \mathrm{~s}^{-1} \\
\% \text { of } 240 \mathrm{nmol} \mathrm{ATP}(\mathrm{g} \mathrm{DW})^{-1} \mathrm{~s}^{-1}\end{array}$ & $\begin{array}{l}24.7 \\
16.5 \\
36.7\end{array}$ & $\begin{array}{r}9.7 \\
6.4 \\
14.4\end{array}$ & $\begin{array}{l}5.5 \\
3.6 \\
8.1\end{array}$ & $\begin{array}{l}2.4 \\
2.6 \\
2.4\end{array}$ & $\begin{array}{l}\text { Bouma (unpublished data) } \\
\text { Lambers et al. (1983) } \\
\text { Poorter et al. (1991) }\end{array}$ \\
\hline $\begin{array}{l}\text { Fraction of root maintenance costs } \\
\% \text { of } 48 \mathrm{nmol} \text { ATP }(\mathrm{g} \mathrm{DW})^{-1} \mathrm{~s}^{-1} \\
\% \text { of } 24 \mathrm{nmol} \text { ATP }(\mathrm{g} \mathrm{DW})^{-1} \mathrm{~s}^{-1} \\
\% \text { of } 18 \mathrm{nmol} \text { ATP }(\mathrm{g} \mathrm{DW})^{-1} \mathrm{~s}^{-1}\end{array}$ & $\begin{array}{l}186 \\
367 \\
490\end{array}$ & $\begin{array}{r}73 \\
144 \\
190\end{array}$ & $\begin{array}{r}41 \\
81 \\
107\end{array}$ & $\begin{array}{l}2.4 \\
2.4 \\
2.3\end{array}$ & $\begin{array}{l}\text { Bouma et al. (unpublished results) } \\
\text { Poorter et al. (1991) } \\
\text { Veen (1980) }\end{array}$ \\
\hline
\end{tabular}

efflux is underestimated if re-uptake from the medium occurs. In labelling studies this problem is regarded as being small, because re-uptake of the labelled ions is statistically less likely due to the excess of unlabeled ions (Jackson et al. 1976). In EC measurements this stochastic process is absent. Re-uptake will depend on (1) the external concentration (and thus measuring period) and (2) the $K_{m}$ and $V_{\max }$ of the uptake system. These uptake parameters vary with nutrient supply over days (Lee and Drew 1986, Siddiqi et al. 1990). However, large changes are not likely to occur within 30 min. For example, Clarkson (1986) mentions that cells that have never been exposed to nitrate, upon exposure increase their nitrate uptake capacity from the constitutive level $\left[1 \mu \mathrm{mol}(\mathrm{g} \mathrm{FW})^{-1} \mathrm{~h}^{-1}\right]$ so that, after a lag period of 0.5 to $1.5 \mathrm{~h}$, they reach a 2 to 5 times higher steady state level after 4 to $6 \mathrm{~h}$ (Fig. 1 in Clarkson 1986). De novo protein synthesis is involved in these adaptations (Fig. 2A in Clarkson 1986). Although the external anion concentration rises to about $100 \mu M$ after $2 \mathrm{~h}$ (cf. Fig. 2), this concentration is only $1 \%$ of that of the growth medium ( $9.0 \mathrm{~m} M$ anions). Therefore, influx will be much lowered under these conditions. This notion is supported by our preliminary comparison, where the open and the closed system (Fig. 1) did not show different efflux rates. The second possible cause of underestimating the efflux rate, is a fast re-uptake within the tissue (from the cell wall) relative to the exchange between tissue and well-stirred medium. This possibility is more likely in a complex tissue than in a unicellular system. However, this problem relates to both labelling studies (described in a model by Morgan et al. 1972) and EC measurements alike, and cannot be resolved with present-day techniques.

In summary, EC measurements have the advantage that an overall measure for all ions is obtained. Incubation for more than about an hour should be avoided, as efflux will be affected both by the lack of calcium and by re-uptake from the medium. However, during short-term experiments these problems are expected to be small. Re-uptake from within the tissue cannot be assessed in any of the experimental ap-

Tab. 2. Half-life $\left(t_{1 / 2}\right)$ of ions in different plant compartments as derived from the literature and measured for calcium in the present experiments. The ratio Cyt/Dp indicates the ratio between the half-life of the cytosolic ions and the Donnan phase $\left(\mathrm{P}_{\mathrm{i}}\right.$ and $\left.{ }^{5} \mathrm{NH}_{4}^{+}\right)$, or the free space when no data on the Donnan phase were available $\left({ }^{13} \mathrm{NO}_{3}^{-}\right)$.

\begin{tabular}{|c|c|c|c|c|c|c|c|c|}
\hline \multirow[t]{2}{*}{ Ions } & \multicolumn{6}{|c|}{$t_{1 / 2}(\min )$} & \multirow{2}{*}{$\begin{array}{l}\text { Ratio } \\
\text { Cyt/Dp }\end{array}$} & \multirow[t]{2}{*}{ References } \\
\hline & WFS & $\mathrm{Dp}$ & FS & Cell & Cyt & Vacuole & & \\
\hline$P_{i}$ & $\begin{array}{l}2.69 \\
2.2\end{array}$ & 11.5 & & 25.9 & 111 & $26.3 \times 60$ & 9.7 & $\begin{array}{l}\text { Lefebvre and Clarkson (1984) } \\
\text { Ron et al. (1988) }\end{array}$ \\
\hline${ }^{15} \mathrm{NH}_{4}^{+}$ & 1.89 & 11.5 & & & 35.5 & $15.5 \times 60$ & 3.1 & Macklon et al. (1990) \\
\hline${ }^{15} \mathrm{NO}_{3}^{-}$ & 5.8 & & & & 126 & $140 \times 60$ & & Macklon et al. (1990) \\
\hline${ }^{13} \mathrm{NO}_{3}^{-}$ & & & 0.5 & & 7 & & 14.0 & Siddiqi et al. (1991) \\
\hline $\mathrm{Ca}^{2+}$ & & 9 & & & & & & Present paper \\
\hline
\end{tabular}


Tab. 3. Leakage rates for anions as derived from the literature for various species and experimental conditions. The literature data were obtained for roots by labelling techniques. Some authors indicate the origin of the efflux. This is shown by the superscripts, ${ }^{c}{ }^{c+v}$ and in for cytosol, cytosol with vacuole and inner space, respectively. For some data, indicated by ${ }^{*}$, it is not clear whether weights are for fresh or dry matter.

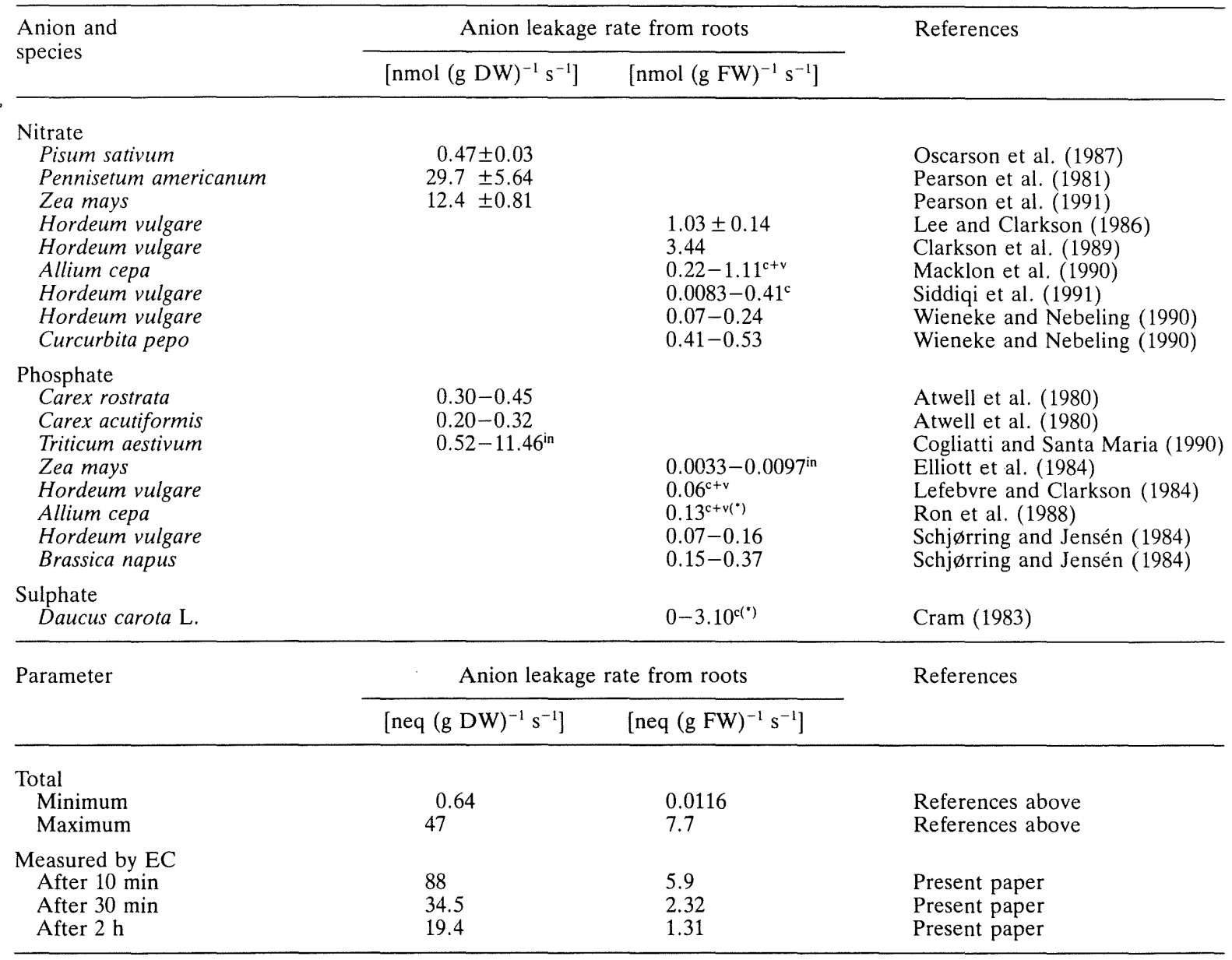

proaches presently available. Therefore, we regard the present data as an adequate estimate for calculating the energy costs for maintenance of ion concentrations in roots.

\section{Interpretation of efflux kinetics}

Efflux from the free space needs to be excluded from total root efflux when calculating energy costs of reuptake balancing efflux. From the calcium exchange rate, we calculated the half-life of the slowest component of the free space (Donnan phase) to be $9 \mathrm{~min}$. This half-life agrees well with literature values (Tab. 2) obtained by compartmental analysis (Baker and Hall 1988) in labelling experiments. Because these data have been derived for multi-cellular systems (intact roots or root segments), results should be considered with care. The internal localization of the cellular compartments within the tissue might hamper a straightforward interpretation; numerous conditions must be met for a proper analysis (Baker and Hall 1988, Zierler 1981). Also, the half-life values vary strongly, e.g. depending on whether ${ }^{15} \mathrm{~N}$ or ${ }^{13} \mathrm{~N}$ label is used (Macklon et al. 1990). However, we regard our estimated half-life reliable, as it is obtained by an alternative method, agreeing well with most of these literature values (Tab. 2).

The overall initial efflux [ca $250 \mathrm{neq}(\mathrm{g} \mathrm{DW})^{-1} \mathrm{~s}^{-1}$ ] originates from Dp, WFS, cytosol and vacuole. As the half-life of the Donnan phase is $9 \mathrm{~min}$, after $30 \mathrm{~min}$ at most $25 \mathrm{neq}(\mathrm{g} \mathrm{DW})^{-1} \mathrm{~s}^{-1}$ originates from the free space and thus at least 44 neq $(\mathrm{g} \mathrm{DW})^{-1} \mathrm{~s}^{-1}$ (i.e. 69 less 25 ; Fig. 2) from the symplast. Using the ratio between the half-lives of cytosol and of Donnan phase as calculated in Tab. 2, the half-life of efflux from the cytosol is expected to be between 126 (i.e. $14 \times 9$ ) and 28 (i.e. $3.1 \times 9) \mathrm{min}$. Regarding these extremes, after $30 \mathrm{~min}$ the initial cytosolic efflux rate would be underestimated by ca 8 to 49 neq $(\mathrm{g} \mathrm{DW})^{-1} \mathrm{~s}^{-1}$ (i.e. 18 to $110 \%$ of the cellular efflux after $30 \mathrm{~min}$ ). Because this expected underestimation overlaps the expected overestimation due 
to efflux from the free space [i.e. at most 25 neq ( $\mathrm{g}$ $D W)^{-1} \mathrm{~s}^{-1}$, we regard the efflux after ca $30 \mathrm{~min}$ as an adequate estimate of the efflux rate from the symplast, and thus suitable as input for calculating the energy costs of maintaining concentrations. Efflux rates after 10 min and $2 \mathrm{~h}$ were used to illustrate the relative effects of increase or decrease of the efflux on the costs for re-uptake of ions lost by efflux (Tab. 1).

The efflux calculated after $30 \mathrm{~min}$ is relatively high (Tab. 3), especially when considering that part of the literature data from the labelling studies were not corrected for initial efflux rates from the free space. Possible reasons for this high value are: (a) all anions are included in efflux, (b) nutrient supply was high during growth, (c) some organic ions may have been present, or (d) perturbation effects lasted for more than $30 \mathrm{~min}$, but do not occur in labelling studies. Treatments can influence membrane potential and thus ion transport (Rincon and Hanson 1986), ion uptake (Bloom and Sukrapanna 1990) and root pressure (Miller 1987). The labelling studies in the literature show a large variation in ion efflux from roots (Tab. 3), probably partly due to different experimental conditions and interpretation of efflux kinetics.

However, the obtained efflux expressed as fraction of influx agrees well with values determined by means of isotopes. Efflux amounted to $50-85 \%\left({ }^{36} \mathrm{ClO}_{3}^{-}\right.$; cited in Clarkson 1985), $63 \%\left({ }^{15} \mathrm{~N}\right.$ and ${ }^{13} \mathrm{~N}$; Tab. 5 in Clarkson et al. 1989$)$ or up to $88 \%\left({ }^{15} \mathrm{~N}\right.$; Tab. 1 in Pearson et al. 1981). In the present experiments, root net $N$ uptake was estimated from the product of plant RGR $(0.15 \mathrm{~g}$ $\mathrm{g}^{-1}$ day $\left.^{-1}\right), \mathrm{N}$ content $\left.[4.13 \mathrm{mmol} \mathrm{N} \text { (g DW plant })^{-1}\right]$ and

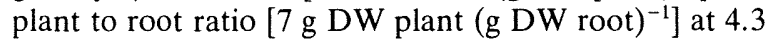
mmol $\mathrm{N} \mathrm{g}^{-1}$ day $^{-1}$ or $50 \mathrm{nmol} \mathrm{N} \mathrm{g}{ }^{-1} \mathrm{~s}^{-1}$. When assuming anion efflux to consist predominantly of nitrate and thus assuming other anions to be negligible, efflux rate equals $100 \times 34.5 /(50+34.5)=41 \%$ of nitrate influx (Influx $=\mid$ Efflux $\mid+$ Net uptake $)$. Comprising other anions yields a slightly lower value (e.g. $34 \%$ assuming phosphate and sulfate to be $10 \%$ of nitrate in- and efflux).

In summary, the efflux rate observed after $30 \mathrm{~min}$ is a good estimate of the initial efflux from the symplast. Although the absolute value of this efflux rate is high (Tab. 3), the relative efflux rate as fraction of the influx rate is lower than the highest values found in the literature.

\section{Comparison of respiratory costs of re-uptake to respiration rates}

Table 3 compares the calculated respiration rates for re-uptake with the average overall and maintenance respiration of roots. For the data of Poorter et al. (1991) we estimated an average value for the species with an RGR of less than $0.2 \mathrm{~g}(\mathrm{~g} \mathrm{DW})^{-1}$ day $^{-1}$, as the efflux was measured on potato plants with a RGR of only 0.15 $\mathrm{g}(\mathrm{g} \mathrm{DW})^{-1}$ day $^{-1}$. The respiration rates of potato roots were transformed to an ATP basis by assuming a $\mathrm{P} / \mathrm{O}_{2}$ ratio of 4.8 [after Tab. 3 in Poorter et al. (1991) for plants with a RGR less than $0.2 \mathrm{~g}(\mathrm{~g} \mathrm{DW})^{-1}$ day $\left.^{-1}\right]$. The overall root respiration of potato was measured on young roots with a higher RGR [i.e. $0.21 \mathrm{~g}(\mathrm{~g} \mathrm{DW})^{-1}$ $\mathrm{day}^{-1}$ ] than the plants used in the present experiments, whereas maintenance respiration was estimated on roots with a similar RGR. The data of Veen (1980) were transformed using a dry matter content of $7 \%$ (B.W. Veen, personal communication) and a $\mathrm{P} / \mathrm{O}_{2}$-ratio of 4.6 mol ATP $\left(\mathrm{mol} \mathrm{O}_{2}\right)^{-1}(\mathrm{~B}$. W. Veen, personal communication).

The respiration rate calculated for re-uptake after 30 min can easily explain the total maintenance respiration rate indicated by Poorter et al. (1991) and Veen (1980), and up to $73 \%$ of the maintenance costs of potato (Tab. 1). Before concluding that maintenance of ion gradients is the most important maintenance process, it is necessary to consider the estimates of maintenance respiration. All these values are obtained by the multiple regression method, as introduced by Veen (1980). In this statistical method, respiration rate is attributed to growth, ion uptake and maintenance as far as it correlates with the rate of dry weight increase, ion uptake rate, or root biomass, respectively. Depending on the presumed mechanism of efflux (e.g. slip of carrier or membrane permeability), re-uptake balancing efflux is expected to correlate with either ion uptake or root biomass. Thus, in the regression approach, costs for re-uptake of ions lost by efflux might be incorporated in the costs for uptake or maintenance. Our present calculations suggest that either a (major) part of these costs is included in the uptake costs instead of in the maintenance coefficient, or maintenance of ion gradients is indeed the quantitatively most important maintenance process. The latter inference is highly unlikely as Van der Werf et al. (1992) calculated that protein turnover accounts for $24-48 \%$ of the maintenance costs of roots, indicating that the maintenance of gradients is not the only maintenance process in roots. Moreover, the specific energy costs of protein turnover as used by Van der Werf et al. (1992) may have been underestimated by a factor 2 to 4 (cf. De Visser et al. 1992). Therefore, we hypothesize that energy costs for re-uptake balancing efflux are predominantly included in the regression coefficients of uptake. This contention is supported by the findings of Van der Werf et al. (1988) and Clarkson (1985; based on the data of Veen, 1980), who both calculated uptake costs to be twice as high as theoretically expected.

The energy costs of re-uptake balancing efflux may be assessed relative to the costs of net uptake and influx. Clarkson (1985) presented a mechanistic account of the energy costs of root ion uptake. We revised some of his assumptions according to more recent findings. The proton/ATP stoichiometry was considered to be 2 (as measured for the tonoplast; Bennett and Spanswick 1984, Guern et al. 1989). Two active membrane pas- 
sages were assumed for ion uptake into the xylem, as Marschner (1989) indicates that xylem loading might be active and most ions will be transported into the xylem. However, in re-uptake balancing efflux from the symplast to external medium, only one membrane interface is involved. At a net anion uptake rate of $16.7 \mathrm{nmol}(\mathrm{g}$ DW root $)^{-1} \mathrm{~s}^{-1}\left(60 \mu \mathrm{mol} \mathrm{g} \mathrm{g}^{-1} \mathrm{~h}^{-1}\right.$; Clarkson 1985) and two membrane passages per ion, costs of net anion uptake are $35 \mathrm{nmol}$ ATP (g DW root) ${ }^{-1} \mathrm{~s}^{-1}$. The calculated influx costs equal the sum of the costs for efflux (Tab. 1; assuming efflux of nitrate only) and net uptake, i.e. $69.5 \mathrm{nmol}$ ATP (g DW root) $)^{-1} \mathrm{~s}^{-1}$. In this case, efflux costs are ca $50 \%$ of influx costs. Considering the efflux of all anions, this value becomes negligibly lower [e.g. efflux costs become $32.8 \mathrm{nmol}$ ATP (g DW root) ${ }^{-1}$ $\mathrm{s}^{-1}$ and thus $48 \%$ of the influx costs, when assuming phosphate and sulfate to be $10 \%$ each of the efflux]. In our plants, nitrate uptake rate was $50 \mathrm{nmol} \mathrm{N}$ (g DW root $)^{-1} \mathrm{~s}^{-1}$, giving an ATP hydrolysis rate of $100 \mathrm{nmol}$ ATP ( $\mathrm{g}$ DW root $)^{-1} \mathrm{~s}^{-1}$. Here, influx costs for nitrate equal $135 \mathrm{nmol}$ ATP $\mathrm{g}^{-1} \mathrm{~s}^{-1}$. Efflux costs are $26 \%$ of influx costs, and ca $10 \%$ of total root respiration of young potato plants.

In conclusion, the energy costs of the re-uptake that balances efflux, are clearly a significant part of influx costs (ca $25-50 \%$ ) and respiration in roots.

Acknowledgements - The skilful contributions of B.O.M. Dirks, M. J. de Kock, A. R. Kowsoleea, C. van der Weele and the members of the analytical laboratory, as well as the critical reading and helpful suggestions of $H$. Lambers, R. Rabbinge, S.C. van de Geijn and B.W. Veen are gratefully acknowledged.

\section{References}

Amthor, J.S. 1984. The role of maintenance respiration in plant growth. - Plant Cell. Environ. 7: 561-569.

Anonymous. 1978. CRC Handbook of Chemistry and Physics $59^{\text {th }}$ Ed.; A Ready-reference Book of Chemical and Physical Data (R. C. Weast, M. J. Astle, eds), p. D-205. CRC Press Inc., Boca Raton, FL. ISBN 0-8493-0549-8.

Atwell, B. J., Veerkamp, M. T., Stuiver, C. E. E. \& Kuiper, P. J. C. 1980. The uptake of phosphate by Carex species from oligotrophic to eutrophic swamp habitats. - Physiol. Plant. 49: 487-494.

Baker, D. A, \& Hall, J. L. 1988. Introduction and general principles. - In Solute Transport in Plant Cells and Tissues (D. A. Baker and J. L. Hall, eds), pp. 1-27. Longman Scientific and Technical, Essex. ISBN 0-582-00580-9.

Bennett, A.B. \& Spanswick, R. 1984. $\mathrm{H}^{+}$-ATPase activity from storage tissue of Beta vulgaris. - Plant Physiol. 74: 545-548.

Bloom, A. J. \& Sukrapanna, S. S. 1990. Effects of exposure to ammonium and transplant shock upon the induction of nitrate absorption. - Plant Physiol. 94: 85-90.

Borochov, A. \& Faragher, J. 1983. Comparison between ultraviolet irradiation an ethylene effects on senescence parameters in carnation flowers. - Plant Physiol. 71: 536-540.

Bouma, T. J., Spitters, C. J. T. \& De Visser, R. 1992. Variation in leaf respiration rate between potato cultivars: effect of developmental stage. - In Molecular, Biochemical and Physiological Aspects of Plant Respiration (H. Lambers and L. H. W. van der Plas, eds), pp. 512-522. SPB Academic Publishing, The Hague. ISBN 90-5103-079-7.
Chang, R. 1981. Electrolyte solutions. - In Physical Chemistry with applications to Biological Systems, pp. 198-204. Macmillian Publishing Co., Inc., New York, NY. ISBN 0-02321040-0.

Clarkson, D. T. 1985. Factors affecting mineral nutrient acquisition by plants. - Annu. Rev. Plant Physiol. 36: 77-115.

- 1986. Regulation of the absorption and release of nitrate by plant cells: A review of current ideas and methodology. - In Fundamental, Ecological and Agricultural Aspects of Nitrogen Metabolism in Higher Plants (H. Lambers, J. J. Neeteson and I. Stulen, eds), pp. 3-27. Martinus Nijhoff Publishers, Dordrecht. ISBN 90-247-3258-1.

- , Saker, L. R., Purves, J. V. 1989. Depression of nitrate and ammonium transport in barley plants with diminished sulphate status. Evidence of co-regulation of nitrogen and sulphate intake. - J. Exp. Bot. 40: 953-963.

Cogliatti, D. H. \& Santa Maria, G. E. 1990. Influx and efflux of phosphorus in roots of wheat plants in non-growth-limiting concentrations of phosphorus. - J. Exp. Bot. 41: 601607.

Cram, J. 1983. Characteristics of sulfate transport across plasmalemma and tonoplast of carrot root cells. - Plant Physiol. 72: 204-211.

Demarty, M., Morvan. C. \& Thellier, M. 1984. Calcium and the cell wall. - Plant Cell Environ. 7: 441-448.

De Visser, R., Spitters, C. J. T. \& Bouma, T. J. 1992. Energy cost of protein turnover: theoretical calculation and experimental estimation from regression of respiration on protein concentration of full-grown leaves. - In Molecular, Biochemical and Physiological Aspects of Plant Respiration (H. Lambers and L. H. W. van der Plas, eds), pp. 493-508. SPB Academic Publishing, The Hague. ISBN 90-5103079-7.

Elliot, G. C., Lynch, J. \& Läuchli, A. 1984. Influx and efflux of $\mathrm{P}$ of roots in intact maize plants. - Plant Physiol. 72: 204-211.

Ferguson, I. B. 1984. Calcium in plant senescence and fruit ripening. - Plant Cell Environ. 7: 477-489.

Guern, J., Mathieu, Y., Kurdjian, A., Manigault, P., Manigault, J., Gillet, B., Beloeil, J. C. \& Lallemand, J. Y. 1989. Regulation of vacuolar $\mathrm{pH}$ in plant cells. II. A ${ }^{31} \mathrm{P}$ NMR study of the modifications of vacuolar $\mathrm{pH}$ in isolated vacuoles induced by proton pumping and cation $/ \mathrm{H}^{+}$exchanges. Plant Physiol. 89: 27-36.

Hanson, J. B. 1984. The functions of calcium in plant nutrition. - In Advances in Plant Nutrition. Vol. 1 (P. B. Tinker and A. Läuchli, eds); pp. 149-208. Praeger Publishers, New York, NY. ISSN 0743-8931.

Hedrich, R. \& Schroeder; J. I. 1989. The physiology of ion channels and electrogenic pumps in higher plants. - Annu. Rev. Plant Physiol. 40: 539-569.

Hetherington, P. R., Broughton, H. L. \& McKersie, B. D. 1988. Ice-encasement injury to microsomal membranes isolated from winter wheat crowns. - Plant Physiol. 86: 740743 .

Hoagland, D. R. \& Snijder, W. C. 1933. Nutrition of strawberry plants under controlled conditions. - Proc. Am. Soc. Hortic. Sci. 30: 288-294.

Jackson, W. A., Kwik, K. D., Volk, R. J. \& Butz, R. G. 1976. Nitrate influx and efflux by intact wheat seedlings: effects of prior nitrate nutrition. - Planta 132: 149-156.

Lambers, H. 1985. Respiration in intact plants and tissues: its regulation and dependence on environmental factors, metabolism and invaded organisms. - In Encyclopedia of Plant Physiol., New Series, Vol. 18 (R. Douce and D. A. Day, eds), pp. 418-473. Springer-Verlag, Berlin. ISBN 3-54013935-4.

- , Day, D. A. \& Azcón-Bieto, J. 1983. Cyanide-resistant respiration in roots and leaves. Measurements with intact tissues and isolated mitochondria. - Physiol. Plant. 58: 148-154.

Lauer, M. J., Blevins, D. G. \& Sierzputowska-Gracz, H. 1989. 
${ }^{31} \mathrm{P}$-Nuclear Magnetic Resonance determination of phosphate compartmentation in leaves of reproductive soybeans (Glycine $\max$ L.) as affected by phosphate nutrition. Plant Physiol. 89: 1331-1336.

Lee, R. B. \& Clarkson, D. T. 1986. Nitrogen-13 studies of nitrate fluxes in barley roots; I compartmental analysis from measurements of ${ }^{13} \mathrm{~N}$ efflux. - J. Exp. Bot. 37: 17531767

- \& Drew, M. C. 1986. Nitrogen-13 studies of nitrate fluxes in barley roots. - J. Exp. Bot. 37: 1768-1779.

Lefebvre, D. D. \& Clarkson, D. T. 1984. Compartmental analysis of phosphate in roots of intact barley seedlings. Can. J. Bot. 62: 1076-1080.

Lewis, J. C. \& Powers, W. L. 1941. Antagonistic action of chlorides on the toxicity of iodides to corn. - Plant Physiol. 16: $393-398$.

Lühring, H. \& Tazawa, M. 1985. Effect of cytoplasmic $\mathrm{Ca}^{2+}$ on the membrane potential and membrane resistance of Chara plasmalemma. - Plant Cell Physiol. 26: 635-646.

Macklon, A. E.S., Ron, M. M. \& Sim, A. 1990. Cortical cell fluxes of ammonium and nitrate in excised root segments of Allium cepa L.; studies using ${ }^{15}$ N. - J. Exp. Bot. 41: 359370.

Marschner, H. 1989. Mechanism of ion release into the xylem. - In Mineral Nutrition of Higher Plants third printing, pp. 62-64. Academic Press Limited, London. ISBN 0-12473541-X.

Miller, D. M. 1987. Errors in the measurement of root pressure and exudation volume flow rate caused by damaging during the transfer of unsupported roots between solutions. Plant Physiol 85: 164-166.

Morgan, M. A., Volk, R. J. \& Jackson, W. A. 1972. Simultaneous influx and efflux of nitrate during uptake by perennial ryegrass. - Plant Physiol. 51: 267-272.

O'Donovan, J. T., O'Sullivan, P. A. \& Caldwell, C. D. 1983. Basis for antagonism of paraquat phytotoxicity to barley by MCPA dimethylamine. - Weed Res. 23: 165-172.

Oscarson, P., Ingemarsson, B., af Ugglas, M. \& Larsson, C.-M. 1987. Short-term studies of $\mathrm{NO}_{3}^{-}$uptake in Pisum using ${ }^{13} \mathrm{NO}_{3}^{-}$. - Planta 152: 319-324.

Pearson, C.J., Volk, R.J. \& Jackson, W. A. 1981. Daily changes in nitrate influx, efflux and metabolism in maize and pearl millet. - Planta 152: 319-324.

Penning de Vries, F. W. T. 1975. The costs of maintenance processes in plant cells. - Ann. Bot. 39: 77-92.

Poorter, H., van der Werf, A., Atkin, O. K. \& Lambers, H. 1991. Respiratory energy requirements of roots vary with the potential growth rate of a plant species. - Physiol. Plant. 83: 469-475.

Rincon, M. \& Hanson, J. B. 1986. Controls on calcium ion fluxes in injured or shocked corn root cells: importance of proton pumping and cell membrane potential. - Physiol. Plant. 67: 576-583.

Ron, M. M., Macklon, A. E. S. \& Sim, A. 1988. Cortical cell fluxes of phosphate in excised root segments of Allium cepa L. - J. Exp. Bot. 39: 1699-1707.

Schjørring, J. K. \& Jensén, P. 1984. Phosphorus nutrition of barley, buckwheat and rape seedlings. II. Influx and efflux of phosphorus by intact roots of different P status. - Physiol. Plant. 61: 584-590.

Senaratna, T., Gusse, J.F. \& McKersie, B. D. 1988. Ageinduced changes in cellular membranes of imbibed soybean seed axes, - Physiol. Plant. 73: 85-91.

Sentenac, H. \& Grignon, C. 1981. A model for predicting ionic equilibrium concentrations in cell walls. - Plant Physiol. 68: $415-419$.

Siddiai, M. Y, Glass, A. D. M. Ruth, T. J. \& Rufty, T. W. 1990. Studies of the uptake of nitrate in barley. I. Kinetics of ${ }^{13} \mathrm{NO}_{3}^{-}$influx. - Plant Physiol. 93: 1426-1432.

- Glass, A. D. M \& Ruth. T. J. 1991. Studies of the uptake of nitrate in barley. III. Compartmentation of $\mathrm{NO}_{3}^{-} .-\mathrm{J}$. Exp. Bot. 42: 1455-1463.

Tomos, A.D. \& Wyn Jones, R. G. 1988. Some transport properties of cells within tissues. - In Solute Transport in Plant Cells and Tissues (D. A. Baker and J. L. Hall, eds), pp. 220-250. Longman Scientific and Technical, Essex. ISBN 0-582-00580-9.

Van der Werf, A., Kooiman, A., Welschen, R. \& Lambers, H. 1988. Respiratory energy costs for the maintenance of biomass, for growth and for ion uptake in roots of Carex diandra and Carex acutiformis. - Physiol. Plant. 72: 438491

- , Van den Berg, G., Ravenstein, H. J. L., Lambers, H. \& Eising, R. 1992. Protein tumover: a significant component of maintenance respiration in roots. - In Molecular, Biochemical and Physiological Aspects of Plant Respiration (H. Lambers and L. H. W. van der Plas, eds), pp. 483-492. SPB Academic Publishing, The Hague. ISBN 90-5103079-7.

Veen, B. W. 1980. Energy costs of ion transport, - In Genetic Engineering of Osmoregulation. Impact on Plant Productivity for Food, Chemicals and Energy (D. W. Rains, R. C. Valentine and C. Holaender, eds), pp. 187-195. Plenum Press, New York, NY. ISBN 0-306-40454-0.

Wieneke, J. \& Nebeling, B. 1990. Improved method for ${ }^{13} \mathrm{~N}$ application in short-term studies on $\mathrm{NO}_{3}^{-}$fluxes in barley and squash plants. $-\mathrm{Z}$. Pflanzenernähr. Bodenk. 153: 117123.

Williamson, R. E. \& Ashley, C. C. 1982. Free Ca ${ }^{2+}$ and cytoplasmic streaming in the alga Chara. - Nature 296: 647-651.

Zierler, K. 1981. A critique of compartmental analysis. Annu. Rev. Biophys. Bioeng. 10: 531-562. 